\title{
Postnatal nutrition alters body composition in adult offspring exposed to maternal protein restriction
}

\author{
Alison K. Gosby ${ }^{1,2} *$, Lisa M. L. Stanton ${ }^{1}$, Christopher A. Maloney ${ }^{1,3}$, Madeleine Thompson ${ }^{4}$, Julie Briody ${ }^{4}$, \\ Robert C. Baxter ${ }^{5}$, Janet M. Bryson ${ }^{1}$, Gareth S. Denyer ${ }^{1}$ and Ian D. Caterson ${ }^{1,3}$ \\ ${ }^{1}$ Human Nutrition Unit, The University of Sydney, NSW, Australia \\ ${ }^{2}$ Present address: School of Biological Sciences, Heydon Laurence Building, A08, The University of Sydney, NSW 2006, Australia \\ ${ }^{3}$ Present address: Institute of Obesity, Nutrition and Exercise, K-25 Medical Foundation Building, The University of Sydney, \\ NSW 2006, Australia \\ ${ }^{4}$ Bone Densitometry, The Children's Hospital at Westmead, NSW, Australia \\ ${ }^{5}$ Kolling Institute of Medical Research, The University of Sydney, NSW, Australia
}

(Received 16 May 2008 - Revised 16 September 2008 - Accepted 29 September 2008 - First published online 5 December 2008)

The insulin-like growth factor (IGF) system is altered with intra-uterine growth retardation and in adult metabolic disease. The aim of the present study was to observe effects of continued protein restriction on the IGF-I system and body composition in offspring of mothers fed a low-protein (LP) diet. Offspring from Wistar dams fed either a $20 \%(\mathrm{CON})$ or $8 \%(\mathrm{LP})$ protein diet during gestation and lactation were studied at birth, $10 \mathrm{~d}$, weaning and at 12 weeks after maintenance on either the $8 \%$ (lp) or $20 \%$ (con) protein diet from weaning. LP offspring had reduced weaning weights $(P<0.05)$ and reduced serum insulin $(P<0.005)$. Serum IGF-I $(P<0.001)$ and acid-labile subunit (ALS) $(P<0 \cdot 0001)$ were reduced at 10 and $21 \mathrm{~d}$. Hepatic expression of IGF-I $(P<0 \cdot 05)$ and ALS $(P<0.005)$ were reduced at 10 and $21 \mathrm{~d}$. IGF binding protein (IGFBP)-1 hepatic expression was elevated at $10 \mathrm{~d}(P<0.001)$ but not at $21 \mathrm{~d}$. Adult LP-con offspring had reduced body weight $(P<0 \cdot 05)$, lean $(P<0 \cdot 0001)$ and bone $(P<0.0001)$ but not fat $(P=0.6)$ mass with no persistent effects on IGF-I, ALS and IGFBP-1.Postnatal lp feeding reduced lean mass $(P<0.0001)$ and bone mass $(P<0.0001)$ in CON and LP animals. Percentage fat (LP $P=0 \cdot 04$; CON $P=0 \cdot 6)$ and IGFBP-1 (LP $P=0 \cdot 01$; CON $P=0.2)$ were increased in LP-lp but not CON-lp offspring. This suggests that postnatal nutrition is important in the effects of maternal protein restriction on adult body composition and that IGFBP-1 may be involved.

Maternal protein restriction: Insulin-like growth factor: Postnatal nutrition: Body composition

Increased adiposity is an important factor in the development of insulin resistance. An increased fat mass with a reduced visceral and lean mass has been shown in the smaller, possibly nutritionally compromised monozygotic twin ${ }^{(1,2)}$ and also in babies from underdeveloped nations ${ }^{(3)}$. In offspring from animal models of intra-uterine growth retardation (IUGR) such as the low protein model of maternal undernutrition there is an increased risk for the development of increased adiposity $^{(4)}$ in adult life. The metabolic pathways leading to this altered body composition could be important contributors to the early onset of metabolic disease that is linked with low birth weight, poor early growth and nutrition ${ }^{(5-7)}$.

A possible candidate contributing to an altered body composition in those exposed to poor early nutrition may be the insulin-like growth factor (IGF)-I system because IGF-I regulates fetal and postnatal growth ${ }^{(8,9)}$. There is evidence to suggest that factors in this system are altered with IUGR. In humans, IGF-I is reduced in IUGR children in comparison with children of normal height and IUGR twins have lower IGF-I but higher IGF binding protein (IGFBP)-1 levels in comparison with appropriate-for-gestational-age co-twins ${ }^{(10,11)}$. Low protein offspring have reduced plasma and liver IGF-I levels and lower hepatic IGF-I expression but do not show any changes in levels of $\operatorname{IGFBP}^{(12,13)}$. A similar reduction in plasma IGF-I levels in addition to an increase in plasma IGFBP-1 levels is seen in pups from energydeprived dams at day 22 of gestation and at postnatal day 9 but the changes in IGF-1 are not present at later time points $^{(14)}$.

It is postulated that changes that may occur as a result of IUGR give a 'predictive adaptive response' where if nutrition remains poor the individual would be at a survival advantage but risk of disease increases once the predictive adaptive response is exceeded ${ }^{(15)}$. In short-term studies low protein offspring maintained on a low-protein diet may have a reduced risk for glucose intolerance or a prolonged time of onset in

Abbreviations: ALS, acid-labile subunit; CON, maternal $20 \%$ protein diet (control); con, post-weaning $20 \%$ protein diet (control); IGF, insulin-like growth factor; IGFBP, insulin-like growth factor binding protein; IUGR, intra-uterine growth retardation; LP, maternal $8 \%$ protein diet (low protein); lp, post-weaning $8 \%$ protein diet (low protein).

* Corresponding author: Dr Alison Gosby, fax +61 29351 4119, email alison.gosby@usyd.edu.au 
comparison with low protein offspring maintained on a normal-protein diet ${ }^{(16)}$. Therefore because IGF-I is nutritionally regulated both pre- and postnatally ${ }^{(8,9)}$ the aim of the present study was to observe any changes in factors of the IGF-I system in low protein offspring that may be modulated by a change in diet from low protein to a normal-protein diet at weaning and be involved in a change in body composition, potentially increasing the risk of metabolic disease.

\section{Experimental methods \\ Diets}

The experimental diets used in the present study include a control $(20 \%$ protein) and a low protein ( $8 \%$ protein) diet. The compositions of these diets are detailed elsewhere ${ }^{(17)}$. The control and low-protein diets were made on-site, in a powdered form. Offspring were allowed up to $40 \mathrm{~g}(650 \mathrm{~kJ}) / \mathrm{d}$. Mated females were given $40 \mathrm{~g} / \mathrm{d}$ during gestation and week 1 of lactation, and 60 and $80 \mathrm{~g} / \mathrm{d}$ on weeks 2 and 3 of lactation respectively. These amounts allowed dams to feed ad libitum (observation). The increase during lactation was to account for increased scatter and food intake by pups.

\section{Experimental animals}

Approval for the present study was obtained from the University of Sydney Animal Ethics Committee. All animals were housed in the Biochemistry Animal House, University of Sydney at $22^{\circ} \mathrm{C}$ on a standard $12 \mathrm{~h}$ light $-12 \mathrm{~h}$ dark cycle. Time-mated female Wistar rats (Animal Resources Centre, Perth, WA, Australia) were randomly assigned to a $20 \%$ protein $(\mathrm{CON} ; n 6)$ or $8 \%$ protein $(\mathrm{LP} ; n$ ) $)$ diet. Dams remained on the assigned diet throughout gestation and lactation. At birth, litter sizes were culled to fifteen or less pups/dam where necessary by reducing female numbers. There was no effect of maternal diet on litter size before (CON, 13.8 (SEM 1.0) (range 10-17); LP, 13.8 (SEM 0.4) (range $12-16) ; P=0.95)$ or after $(\mathrm{CON}, 13.3$ (SEM 0.8) (range 10-15); LP, 13.7 (SEM 0.3) (range 12-15), $P=0.66$ ) culling. At weaning, male offspring from each maternal group were randomly assigned to the $20 \%$ protein (con) or $8 \%$ protein (lp) diet to give four study groups (CONcon, CON-lp, LP-con and LP-lp). Body weights (g) of all offspring were measured weekly from birth.

Male pups were killed by lethal injection of Nembutal (sodium pentobarbitone; $100 \mathrm{mg} / \mathrm{kg}$ body weight) at $10 \mathrm{~d}$ (CON $n$ 8; LP $n$ 9), $21 \mathrm{~d}$ (weaning) (CON $n$ 8; LP $n$ 9) and 12 weeks (CON-con $n$ 8; CON-lp $n$ 9; LP-con $n 9$ and LP$\operatorname{lp} n$ 7) for tissue and blood collection. Tissues were collected in the morning, $1 \mathrm{~h}$ after the removal of food and dams. Livers were immediately frozen in liquid $\mathrm{N}_{2}$ and stored at $-80^{\circ} \mathrm{C}$ for later gene expression analysis. Blood samples were collected by cardiac puncture and serum stored at $-20^{\circ} \mathrm{C}$ until subsequent analysis.

\section{Serum measurements}

A rat insulin RIA kit (Linco Research, St Louis, MO, USA) was used to measure serum insulin concentration. The intraand inter-assay CV for the insulin assay are 4.6 and $9.4 \%$ respectively. Rat acid-labile subunit (ALS), IGF-I and
IGFBP-1 were measured by specific RIA as reported previously $^{(18-20)}$.

\section{Assessment of gene expression}

The expressions of liver IGF-I, ALS and IGFBP-1 were determined using real-time PCR. RNA was extracted from frozen liver and cDNA generated using described methods ${ }^{(21)}$. cDNA was stored at $-20^{\circ} \mathrm{C}$ until use. Primer sequences were designed using Primer Express software (Applied Biosystems, Foster City, CA, USA). The primers used for each gene were as follows: IGF-I, caggctatggctccagcatt (forward) and acatctccagcctcctcagatc (reverse); ALS, ggcctcgacctaagagacgtt (forward) and ggcca-gtaagtagccagtgtca (reverse); IGFBP-1, agctgccgctcaacagaaa (forward) and tgttgcagtttg-gcagataaaatt (reverse); $18 \mathrm{~S}$ rRNA, gacggaccagagcgaaagc (forward) and aacctccgactttcgttcttgatt (reverse). Reactions took place in the ABI Prism 7000 Sequence Detection System (Applied Biosystems) using the SYBR Green two-step PCR protocol (Applied Biosystems). Each reaction mixture contained $25 \mathrm{ng}$ cDNA, SYBR Green Universal Master Mix, forward and reverse primers (final primer concentration $300 \mathrm{~nm}$ ) and sterile water. Tubes were incubated at $50^{\circ} \mathrm{C}$ for $2 \mathrm{~min}, 95^{\circ} \mathrm{C}$ for $10 \mathrm{~min}$ and then cycled at $95^{\circ} \mathrm{C}$ for $15 \mathrm{~s}$ and $60^{\circ} \mathrm{C}$ for $1 \mathrm{~min}$ for forty cycles. The amount of cDNA was calculated relative to the amount of endogenous control (18S rRNA) initially present.

\section{Analysis of body composition}

Dual-energy X-ray absorptiometry measures body composition by quantifying the differences in the X-ray attenuation characteristics of bone and soft tissue. Bone, lean and fat mass were determined using a narrow angle $\left(<5^{\circ}\right)$ fan-beam dual-energy X-ray bone densitometer (Lunar Prodigy; GE Medical Systems, Madison, WI, USA). This machine utilises an X-ray beam with two distinct energy peaks (38 and $70 \mathrm{keV})$. The data were analysed using 'Small Animal', version 6.10 on scans performed at a resolution of approximately $0.6 \times 1.05 \mathrm{~mm}$. Rats were sedated $(15 \mathrm{mg}$ pentobarbitone sodium $/ \mathrm{kg}$ and $25 \mathrm{mg}$ ketamine $/ \mathrm{kg}$ ) and placed in a prone position on the scan table of the densitometer. Limbs were stretched out and placed flat for easier delineation of body regions. Scans, each lasting approximately $1 \mathrm{~min}$, were performed in duplicate. The $\mathrm{CV}$ for bone, fat and lean mass were $0.7,4.0$ and $0.6 \%$ respectively.

\section{Statistical analyses}

Results were analysed by two-way ANOVA testing for maternal and post-weaning diet effects. Fisher's protected least-significance differences post hoc test was used to test for differences between individual groups. Statistical significance was achieved when $P<0 \cdot 05$. All data are expressed as mean values with their standard errors.

\section{Results}

Body weight

At birth, pups from LP dams were significantly lighter than pups from CON dams (CON, 6.15 (SEM 0.06); LP: 5.90 


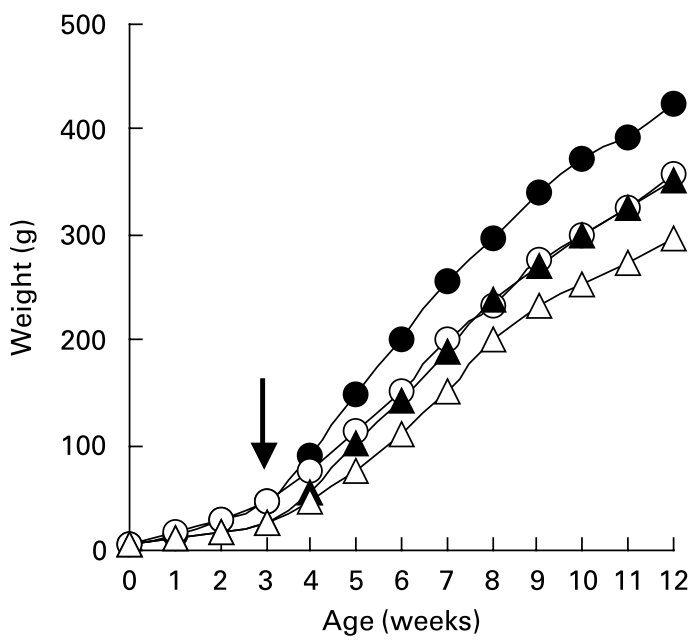

Fig. 1. Body weight growth curves of offspring of dams fed a $20 \%$ protein (control) diet $(\bullet, \bigcirc)$ or an $8 \%$ protein (low-protein) diet $(\boldsymbol{\Lambda}, \Delta)$ maintained on a control $(\bullet, \boldsymbol{\Lambda})$ or low-protein $(\bigcirc, \Delta)$ diet from weaning until age 12 weeks. $\downarrow$, Onset of postnatal diets. Data are means. As the standard errors are smaller than the symbols they have been excluded from the figure.

(SEM 0.06) $\mathrm{g} ; P<0.05$ ) and this difference persisted throughout lactation and into weaning (CON, 44.8 (SEM 0.5); LP, 24.1 (SEM 0.4) g; $P<0.05$ ). Fig. 1 presents the growth curves of each study group until age 12 weeks. LP offspring maintained reduced body weights through to 12 weeks in comparison with $\mathrm{CON}$ offspring independent of post-weaning diet $(P<0.05)$. CON and LP offspring maintained on the $1 p$ diet from weaning demonstrated reduced body weights at 12 weeks when compared with their littermates allocated the con diet at weaning $(P<0 \cdot 05)$.

\section{Body composition}

Table 1 presents body composition data at age 10 weeks. Bone mineral density was reduced in animals exposed to a low-protein diet in utero $(P<0.0001$; ANOVA) and post-weaning $(P<0.0001$; ANOVA); the effects were additive with a further reduction seen in LP-lp animals. Bone mass and density were reduced in LP-con offspring in comparison with CON-con offspring and low protein feeding from weaning led to significant reductions in bone mass and bone mineral density in CON and LP offspring. LP offspring had a reduced lean mass $(P<0.0001$; ANOVA). Lean mass was also reduced in CON and LP offspring as a result of feeding of the lp diet from weaning $(P<0.0001$; ANOVA). Unlike bone and lean mass, fat mass was not affected by maternal $(P=0 \cdot 3$; ANOVA) or post-weaning $(P=0.07$; ANOVA) diet. There was a significant interaction between maternal and post-weaning diet $(P=0 \cdot 04$; ANOVA) where CON-lp animals had a reduced fat mass in comparison with CON-con, an effect of postnatal feeding not seen in LP animals. Once expressed as a percentage of body mass, bone and lean mass were not reduced (data not shown). There was a significant interaction between maternal and post-weaning diet $(P=0.04$; ANOVA) where LP-lp animals had increased percentage fat in comparison with LP-con, an effect not seen in CON animals.

\section{Maternal diet influences on the liver insulin-like growth factor-insulin-like growth factor binding protein expression profile in 10 and $21 \mathrm{~d}$ offspring}

Table 2 shows the IGF-IGFBP gene expression profile in 10 and $21 \mathrm{~d} \mathrm{LP}$ and CON offspring. IGF-I expression was not different between the CON and LP offspring at $10 \mathrm{~d}$ but by $21 \mathrm{~d}$ a significant reduction was evident in LP offspring $(P<0.05)$. ALS gene expression was reduced in the livers of LP offspring at age $10 \mathrm{~d}(P<0.005)$ and $21 \mathrm{~d}(P<0.005)$ in comparison with $\mathrm{CON}$ offspring. IGFBP-1 gene expression was significantly elevated in LP offspring at $10 \mathrm{~d}(P<0.001)$ but not at $21 \mathrm{~d}$.

Maternal diet influences on the serum insulin, insulin-like growth factor-I and acid-labile subunit levels in young offspring

Maternal influences on serum insulin, IGF-I and ALS levels at 10 and $21 \mathrm{~d}$ are shown in Fig. 2. Serum insulin levels have

Table 1. Body compositionł

(Mean values with their standard errors)

\begin{tabular}{|c|c|c|c|c|c|c|c|c|}
\hline & \multicolumn{4}{|c|}{ CON offspring } & \multicolumn{4}{|c|}{ LP offspring } \\
\hline & \multicolumn{2}{|c|}{ con } & \multicolumn{2}{|c|}{ Ip } & \multicolumn{2}{|c|}{ con } & \multicolumn{2}{|c|}{ Ip } \\
\hline & Mean & SEM & Mean & SEM & Mean & SEM & Mean & SEM \\
\hline Bone mass (g) & $9 \cdot 86$ & 0.73 & 7.67†† & 1.00 & $7 \cdot 97^{\star *}$ & 0.82 & 6.91*† & 0.55 \\
\hline Bone mass (\%) & $2 \cdot 66$ & 0.04 & 2.56 & 0.06 & 2.69 & 0.00 & $2 \cdot 74$ & 0.11 \\
\hline BMD & 0.177 & 0.002 & $0.162 † \dagger$ & 0.002 & $0.162^{\star \star}$ & 0.003 & $0.150^{*} \dagger$ & 0.003 \\
\hline Lean $(\mathrm{g})$ & 288.7 & $2 \cdot 6$ & $232.8 \dagger \dagger$ & $8 \cdot 7$ & $227 \cdot 7^{\star \star}$ & $9 \cdot 4$ & $193 \cdot 9^{*} \dagger$ & 8.2 \\
\hline Lean (\%) & $78 \cdot 1$ & 1.6 & 77.4 & $2 \cdot 1$ & $78 \cdot 0$ & $2 \cdot 4$ & 74.9 & 3.0 \\
\hline Fat (g) & $76 \cdot 1$ & $5 \cdot 0$ & $57 \cdot 7 \dagger$ & 5.9 & $61 \cdot 8$ & 3.6 & $63 \cdot 1$ & 3.3 \\
\hline Fat $(\%) \S$ & $20 \cdot 2$ & 1.0 & $19 \cdot 2$ & 1.4 & $20 \cdot 9$ & 1.2 & $24 \cdot 1 \dagger$ & 1.5 \\
\hline
\end{tabular}

CON, maternal $20 \%$ protein diet (control); LP, maternal $8 \%$ protein diet (low protein); con, post-weaning $20 \%$ protein diet (control);

Ip, post-weaning $8 \%$ protein diet (low protein); BMD, bone mineral density.

Mean value was significantly different from that of the CON offspring (maternal diet effect): ${ }^{\star} P<0.05,{ }^{\star \star} P \leq 0.0005$.

Mean value was significantly different from that of the con-fed offspring (post-weaning diet effect): $\uparrow P \leq 0.02, \dagger \dagger P<0.0005$.

$\ddagger$ Dual energy X-ray absorptiometry was used to measure bone surface area $\left(\mathrm{cm}^{2}\right)$, bone mass $(\mathrm{g})$, lean mass $(\mathrm{g})$ and fat mass

(g) in 10-week CON and LP offspring maintained on either a con or Ip diet from weaning (21 d).

$\S$ Fat $(\%)$ is fat mass expressed as a percentage of body weight. 
Table 2. Insulin-like growth factor (IGF)-I-IGF binding protein-1 (IGFBP-1) gene expression profile (arbitrary units) in the livers of $10 \mathrm{~d}$ and $21 \mathrm{~d}$ offspring

(Mean values with their standard errors)

\begin{tabular}{|c|c|c|c|c|c|c|c|c|}
\hline & \multicolumn{4}{|c|}{$10 d$} & \multicolumn{4}{|c|}{$21 d$} \\
\hline & \multicolumn{2}{|c|}{ CON } & \multicolumn{2}{|c|}{ LP } & \multicolumn{2}{|c|}{ CON } & \multicolumn{2}{|c|}{ LP } \\
\hline & Mean & SEM & Mean & SEM & Mean & SEM & Mean & SEM \\
\hline IGF-I & $15 \cdot 3$ & 4.2 & 11.5 & 2.9 & 234.2 & $50 \cdot 0$ & $43 \cdot 5^{\star}$ & $12 \cdot 1$ \\
\hline IGFBP-1 & 3.7 & 0.7 & $8 \cdot 8^{* *}$ & 1.4 & $18 \cdot 6$ & 3.3 & 19.9 & 7.9 \\
\hline ALS & $2 \cdot 6$ & 0.2 & $1.0^{* *}$ & 0.2 & 68.9 & 9.5 & $5 \cdot 7^{\star *}$ & 0.9 \\
\hline
\end{tabular}

CON, maternal $20 \%$ protein diet (control); LP, maternal $8 \%$ protein diet (low protein); ALS, acid-labile subunit. Mean value was significantly different from that of the CON offspring (maternal diet effect): ${ }^{\star} P<0.05$, ${ }^{\star \star} P \leq 0.005$

previously been shown to be reduced in $10 \mathrm{~d}$ and $26 \mathrm{~d} \mathrm{LP}$ offspring $^{(22)}$ and in the present study were significantly reduced in LP offspring in comparison with CON offspring at $21 \mathrm{~d}(P<0 \cdot 005)$. Circulating IGF-I levels were significantly reduced in LP offspring at $10 \mathrm{~d}(P<0.001)$ and $21 \mathrm{~d}$ $(P<0.001)$ in comparison with $\mathrm{CON}$ offspring. Between 10 and $21 \mathrm{~d} \mathrm{CON}$ offspring experienced a significant increase in serum IGF-I concentrations $(P<0.001)$; this increase did not occur in LP offspring. Circulating ALS levels were also significantly reduced in LP offspring at $10 \mathrm{~d}(P<0.0001)$ and $21 \mathrm{~d}(P<0 \cdot 0001)$ in comparison with $\mathrm{CON}$ offspring. Between 10 and $21 \mathrm{~d}$ there was a significant increase in ALS concentrations in CON $(P<0 \cdot 05)$ but not in LP $(P=0 \cdot 1)$ offspring.

Maternal and post-weaning diet influences on serum insulin and liver insulin-like growth factor-insulin-like growth factor binding protein profile in 12-week offspring

Maternal diet did not have significant effects on serum insulin, IGF-I or ALS concentrations at 12 weeks but did lead to increased IGFBP-1 levels in LP offspring ( $P=0 \cdot 02$; ANOVA). This increase was only significant in those maintained on the lp diet $(P=0.03)$ and not in those maintained on the con diet $(P=0 \cdot 3)$ from weaning.

Post-weaning diet did not affect serum IGF-1 $(P=0.5$; ANOVA) or ALS ( $P=0.1$; ANOVA) levels but did have significant effects on serum insulin $(P<0.05$; ANOVA) and IGFBP-1 ( $P<0.001$; ANOVA) levels (Figs. 3 (a)-(d)). Maintenance on the low-protein diet from weaning resulted in reduced insulin in CON offspring but not in LP offspring. This is possibly because LP offspring tended to maintain reduced insulin independent of postnatal diet, a maternal diet effect that was not significant. Post-weaning feeding of a low-protein diet resulted in an increase in IGFBP-1 levels in LP $(P=0.01)$ but not in CON offspring $(P=0 \cdot 2)$.

\section{Discussion}

The study aimed to observe the effects of continued feeding of a low-protein diet on the IGF system and body composition because manipulation of the postnatal diet can prolong or accelerate the time of onset of glucose intolerance in low protein offspring ${ }^{(22,23)}$. Although there were no persistent changes in IGF-1 and ALS with age in the low protein model, the present study demonstrated that low protein animals fed a low-protein diet from weaning had increased IGFBP-1 levels and percentage fat. These changes were not seen in the LP-con or CON-lp animals, suggesting that postnatal nutrition is important in the long-term effects of maternal protein restriction on body composition and that IGFBP-1 may play an important role. This could have important implications in the prevention of metabolic disease through dietary treatment in IUGR individuals.

The early reductions in circulating IGF-I and ALS levels with corresponding changes in the hepatic expression of IGF-I, IGFBP-1 and ALS in young LP offspring are consistent with the reduced growth in this model and are in agreement with other studies ${ }^{(12)}$. Because undernutrition (via insulin deficiency) leads only to post-translational reductions in ALS, the presence of reductions in both mRNA and protein may indicate delayed maturation of the IGF system in the young LP offspring; this may also contribute to the early reductions in IGF-I ${ }^{(24)}$. IGFBP-1 levels decline in response to a rise in insulin. Young male LP offspring have reduced insulin secretion; therefore, insulin may play an important role in the transient change in IGFBP-1 seen at an early age in the present study. Insulin has been shown to be important in the alterations of IGF and IGFBP secretion and hepatocyte proliferation seen in low protein offspring at an early age ${ }^{(13)}$.

The early changes in the IGF-IGFBP profile as a result of maternal protein restriction were associated with persistent reductions in body weight. However, if LP offspring were maintained on the control diet (20\% protein) from weaning, relative body composition and circulating levels of IGF-I, IGFBP-1 and ALS were similar to CON offspring by the age of 3 months; this may be representative of the maturation of the IGF system in LP-con animals. Maintenance of CON and LP offspring on the low-protein diet from weaning did not have effects on IGF-I and ALS but did lead to reductions in bone mass and lean mass. The reduced lean and bone mass as a result of a postnatal low-protein diet may be partly attributed to reduced insulin found in CON-lp animals in comparison with CON-con animals. The reduced insulin in the CONlp animals may be due to inadequate amino acid supply in the diet, leading to reduced levels of insulin, protein synthesis for lean mass and reduced stimulation of bone growth. In contrast, in comparison with all groups at the age of 3 months LP-lp animals had increased IGFBP-1 levels and increased percentage fat, the latter possibly resulting from a reduced lean mass accumulation. These changes are indicative of an interaction between maternal and postnatal diet. A proposed 

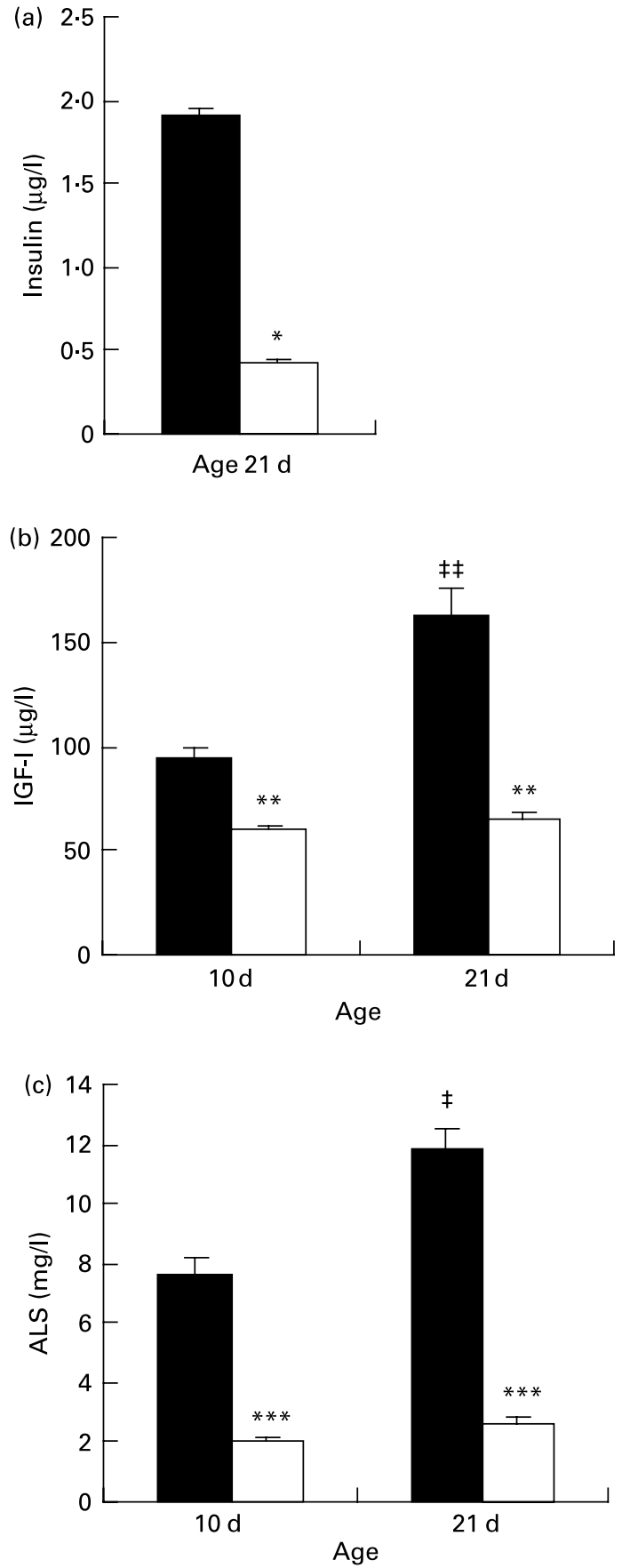

Fig. 2. Maternal diet influences on serum insulin-like growth factor (IGF)-I profile at $10 \mathrm{~d}$ and $21 \mathrm{~d}$. Serum insulin (a), IGF-I (b) and acid-labile subunit (ALS) (c) concentrations in $10 \mathrm{~d}$ and $21 \mathrm{~d}$ offspring of dams fed a $20 \%$ protein (control) diet ( $\square$; CON) or an $8 \%$ protein (low-protein) diet ( $\square$; LP). Data are means, with standard errors represented by vertical bars. Mean value was significantly different from that of the CON offspring (maternal diet effect): ${ }^{\star} P<0.005,{ }^{\star \star} P<0.001,{ }^{\star \star \star} P<0.0001$. Mean value was significantly different from that of the $10 \mathrm{~d}$ old rats of the same maternal diet group (age effect): $\ddagger P<0.05$, $\ddagger$ $P<0.001$.

function of IGFBP-1 is to regulate the bioavailability of IGF-I ${ }^{(9)}$. High IGFBP-1 levels could contribute to a reduction in lean mass accretion ${ }^{(25)}$ and reduced body weight, possibly contributing to the increased percentage fat and changed body composition seen in the present study.
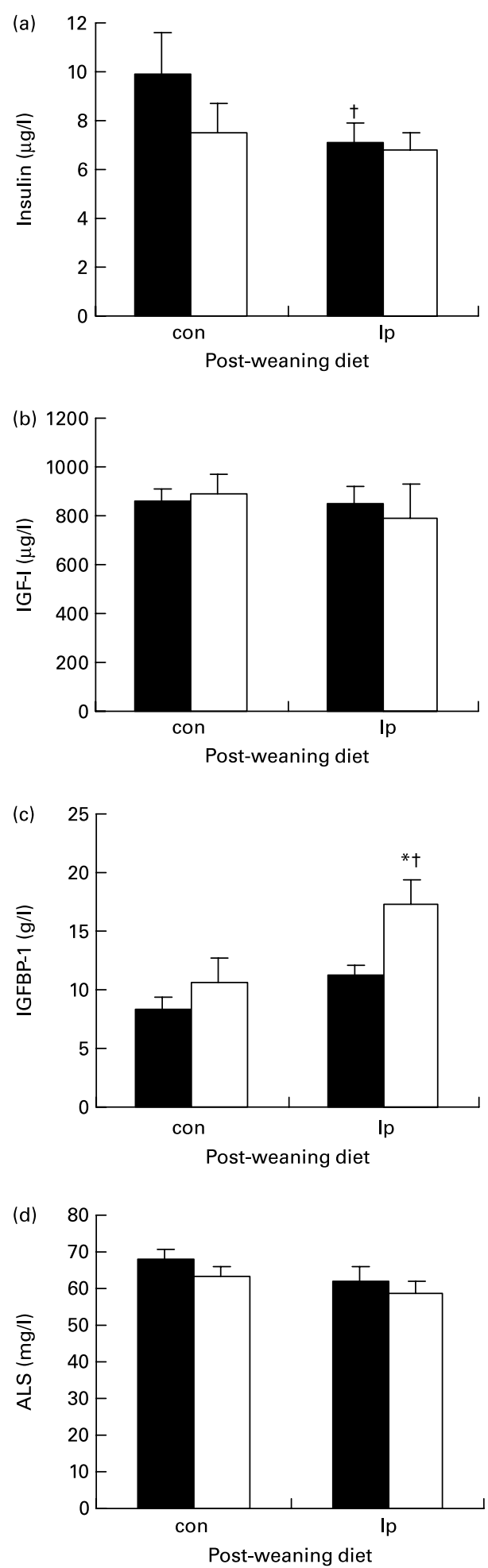

Fig. 3. Maternal and post-weaning dietary influences on serum insulin-like growth factor (IGF)-IGF binding protein (IGFBP) profiles at 12 weeks. Serum insulin (a), IGF-I (b), IGFBP-1 (c) and acid-labile subunit (ALS) (d) concentrations in offspring of dams fed a $20 \%$ protein (control) diet (ם; CON) or an $8 \%$ protein (low-protein) diet ( $\square$; LP) maintained on a control (con) or low-protein (Ip) diet from weaning $(21 \mathrm{~d})$. Data are means, with standard errors represented by vertical bars. *Mean value was significantly different from that of the CON offspring (maternal diet effect) $(P<0.05)$. † Mean value was significantly different from that of the con-fed offspring of the same maternal diet group (post-weaning diet effect) $(P<0.05)$. 
IGFBP-1 is regulated by many factors including nutrition, insulin and anthropometry ${ }^{(26,27)}$. The absence of increased IGFBP-1 levels in the CON-lp animals suggests that acute nutrition is not a primary cause of the increase in IGFBP-1 found in the LP-lp animals. In the present study basal insulin levels tended to remain lower in all LP animals compared with CON-con animals at 3 months and this may be representative of impaired pancreatic function/insulin secretion in the low protein model $^{(23)}$ where young male LP offspring maintained on a normal-protein diet have reduced insulin secretion ${ }^{(22)}$ but an increased glucose tolerance ${ }^{(28)}$ and improved insulin sensitivity (AK Gosby, CA Maloney and ID Caterson, unpublished results). Although there was not a significant reduction in basal insulin levels in LP-lp animals in comparison with LP-con or CON-lp animals, insulin secretion in response to a glucose load is influenced by postnatal diet in low protein offspring. Young male LP offspring fed a low-protein diet from weaning show a reduced insulin response but maintain glucose tolerance in comparison with CON-lp animals ${ }^{(29)}$. This reduced insulin secretion in comparison with CON animals is also seen in response to a high-fat, energy-dense diet (AK Gosby, CA Maloney and ID Caterson, unpublished results). Therefore, the increased basal IGFBP-1 levels seen in the present study could result from reduced insulin excursions.

High IGFBP-1 levels may be protective against vascular disease and low IGFBP-1 levels are associated with the development of glucose intolerance ${ }^{(30-32)}$. Moreover, reduced levels of IGFBP-1 have been shown in elderly individuals who were of low birth weight and may be associated with the effects of fetal programming on insulin resistance ${ }^{(33)}$. Therefore the high IGFBP-1 levels seen in the present study in the LP-lp animals may be either protective against or be an indicator that these animals are at a lower risk for the development of metabolic disease. This is consistent with other studies that show LP animals maintained on an $8 \%$ protein diet from weaning have an improved glucose tolerance in comparison with LP animals maintained on a $20 \%$ protein diet from weaning ${ }^{(16)}$. This does not confirm that continued low protein feeding would prevent metabolic disease. All offspring in the present study were allowed up to $650 \mathrm{~kJ} / \mathrm{d}$. Because dietary protein may be associated with energy intake $^{(34)}$ and satiety ${ }^{(35)}$, an ad libitum feeding protocol could be associated with an increased food intake. In turn, these factors could lead to weight gain, possibly in the form of fat in preference to lean and bone mass and this could contribute to an earlier development of metabolic disease.

The results of the present study suggest that early disruptions in the IGF-IGFBP profile are not permanent but may be sensitive to postnatal nutrition with effects on body composition. The IGF-IGFBP system may be protective of glucose intolerance and CVD; therefore, manipulation of this system with postnatal diet is promising for the prevention of these diseases.

\section{Acknowledgements}

I. D. C., J. M. B., G. S. D., L. M. L. S., A. K. G. and C. A. M. designed the research. L. M. L. S., A. K. G. and C. A. M. performed the research. M. T., J. B. and A. K. G. carried out and analysed dual-energy X-ray absorptiometry scans. A. K. G. and L. M. L. S. analysed the data and wrote the paper. R. C.
B. provided expertise and facilities for the IGF and IGFBP assays. I. D. C., C. A. M. and R. C. B. edited the manuscript. The authors declare no conflict of interest.

A. K G. and L. M. L. S. contributed equally to the study. This research was supported by a project grant from the National Health and Medical Research Council of Australia. We thank Sri Devi Meka and Kevin Hardman at the Kolling Institute for their assistance with the IGF and IGFBP assays. We thank Penfords Australia PL (formerly Starch Australasia) for their kind donation of maize starch and dextrose monohydrate.

\section{References}

1. Loos RJ, Beunen G, Fagard R, et al. (2001) Birth weight and body composition in young adult men - a prospective twin study. Int J Obes Relat Metab Disord 25, 1537-1545.

2. Loos RJ, Beunen G, Fagard R, et al. (2002) Birth weight and body composition in young women: a prospective twin study. Am J Clin Nutr 75, 676-682.

3. Yajnik CS, Fall CH, Coyaji KJ, et al. (2003) Neonatal anthropometry: the thin-fat Indian baby. The Pune Maternal Nutrition Study. Int J Obes Relat Metab Disord 27, 173-180.

4. Guan H, Arany E, van Beek JP, et al. (2005) Adipose tissue gene expression profiling reveals distinct molecular pathways that define visceral adiposity in offspring of maternal proteinrestricted rats. Am J Physiol Endocrinol Metab 288, E663-E673.

5. Hales CN, Barker DJ, Clark PM, et al. (1991) Fetal and infant growth and impaired glucose tolerance at age 64. BMJ 303, 1019-1022.

6. Barker DJ, Hales CN, Fall CH, et al. (1993) Type 2 (non-insulin-dependent) diabetes mellitus, hypertension and hyperlipidaemia (syndrome $\mathrm{X}$ ): relation to reduced fetal growth. Diabetologia 36, 62-67.

7. Hales CN, Desai M, Ozanne SE, et al. (1996) Fishing in the stream of diabetes: from measuring insulin to the control of fetal organogenesis. Biochem Soc Trans 24, 341-350.

8. Baker J, Liu JP, Robertson EJ, et al. (1993) Role of insulin-like growth factors in embryonic and postnatal growth. Cell 75, $73-82$.

9. Underwood LE, Thissen JP, Lemozy S, et al. (1994) Hormonal and nutritional regulation of IGF-I and its binding proteins. Horm Res 42, 145-151.

10. Cutfield WS, Hofman PL, Vickers M, et al. (2002) IGFs and binding proteins in short children with intrauterine growth retardation. J Clin Endocrinol Metab 87, 235-239.

11. Bajoria R, Sooranna SR, Ward S, et al. (2002) Placenta as a link between amino acids, insulin-IGF axis, and low birth weight: evidence from twin studies. J Clin Endocrinol Metab 87, 308-315.

12. Muaku SM, Beauloye V, Thissen JP, et al. (1995) Effects of maternal protein malnutrition on fetal growth, plasma insulinlike growth factors, insulin-like growth factor binding proteins, and liver insulin-like growth factor gene expression in the rat. Pediatr Res 37, 334-342.

13. El-Khattabi I, Gregoire F, Remacle C, et al. (2003) Isocaloric maternal low-protein diet alters IGF-I, IGFBPs, and hepatocyte proliferation in the fetal rat. Am J Physiol Endocrinol Metab 285, E991-E1000.

14. Woodall SM, Breier BH, Johnston BM, et al. (1996) A model of intrauterine growth retardation caused by chronic maternal undernutrition in the rat: effects on the somatotrophic axis and postnatal growth. $J$ Endocrinol 150, 231-242. 
15. Armitage JA, Khan IY, Taylor PD, et al. (2004) Developmental programming of the metabolic syndrome by maternal nutritional imbalance: how strong is the evidence from experimental models in mammals? J Physiol 561, 355-377.

16. Sugden MC \& Holness MJ (2002) Gender-specific programming of insulin secretion and action. $J$ Endocrinol 175, 757-767.

17. Maloney CA, Gosby AK, Phuyal JL, et al. (2003) Site-specific changes in the expression of fat-partitioning genes in weanling rats exposed to a low-protein diet in utero. Obes Res 11, 461-468.

18. Baxter RC \& Dai J (1994) Purification and characterization of the acid-labile subunit of rat serum insulin-like growth factor binding protein complex. Endocrinology 134, 848-852.

19. Crawford BA, Martin JL, Howe CJ, et al. (1992) Comparison of extraction methods for insulin-like growth factor-I in rat serum. $J$ Endocrinol 134, 169-176.

20. Lewitt MS, Saunders H \& Baxter RC (1991) Regulation of rat insulin-like growth factor-binding protein-1, the effect of insulin-induced hypoglycemia. Endocrinology 131, 2357-2364.

21. Bryson JM, Phuyal JL, Proctor DR, et al. (1999) Plasma insulin rise precedes rise in ob mRNA expression and plasma leptin in gold thioglucose-obese mice. Am J Physiol Endocrinol Metab 276, E358-E364.

22. Gosby AK, Maloney CA, Phuyal JL, et al. (2003) Maternal protein restriction increases hepatic glycogen storage in young rats. Pediatr Res 54, 413-418.

23. Wilson MR \& Hughes SJ (1997) The effect of maternal protein deficiency during pregnancy and lactation on glucose tolerance and pancreatic islet function in adult rat offspring. $J$ Endocrinol 154, 177-185.

24. Boisclair YR, Rhoads RP, Ueki I, et al. (2001) The acid-labile subunit (ALS) of the $150 \mathrm{kDa}$ IGF-binding protein complex: an important but forgotten component of the circulating IGF system. $J$ Endocrinol 170, 63-70.

25. Lang CH, Vary TC \& Frost RA (2003) Acute in vivo elevation of insulin-like growth factor (IGF) binding protein-1 decreases plasma free IGF-I and muscle protein synthesis. Endocrinology 144, 3922-3933.
26. Wolk K, Larsson SC, Vessby B, et al. (2004) Metabolic, anthropometric, and nutritional factors as predictors of circulating insulin-like growth factor binding protein-1 levels in middleaged and elderly men. J Clin Endocrinol Metab 89, 1879-1884.

27. Hong Y, Brismar K, Hall K, et al. (1997) Associations between insulin-like growth factor-I (IGF-I), IGF-binding protein-1, insulin and other metabolic measures after controlling for genetic influences: results from middle-aged and elderly monozygotic twins. J Endocrinol 153, 251-257.

28. Shepherd PR, Crowther NJ, Desai M, et al. (1997) Altered adipocyte properties in the offspring of protein malnourished rats. Br J Nutr 78, 121-129.

29. Gosby AK (2005) The low protein model: postnatal diet and insulin sensitivity. PhD thesis. University of Sydney.

30. Heald AH, Siddals KW, Fraser W, et al. (2002) Low circulating levels of insulin-like growth factor binding protein-1 (IGFBP-1) are closely associated with the presence of macrovascular disease and hypertension in type 2 diabetes. Diabetes 51, $2629-2636$.

31. Heald AH, Cruickshank JK, Riste LK, et al. (2001) Close relation of fasting insulin-like growth factor binding protein-1 (IGFBP-1) with glucose tolerance and cardiovascular risk in two populations. Diabetologia 44, 333-339.

32. Sandhu MS, Heald AH, Gibson JM, et al. (2002) Circulating concentrations of insulin-like growth factor-I and development of glucose intolerance: a prospective observational study. Lancet 359, 1740-1745.

33. Kajantie E, Dunkel L, Rutanen EM, et al. (2002) IGF-I, IGF binding protein (IGFBP)-3, phosphoisoforms of IGFBP-1, and postnatal growth in very low birth weight infants. J Clin Endocrinol Metab 87, 2171-2179.

34. Sorensen A, Mayntz D, Raubenheimer D, et al. (2008) Proteinleverage in mice: the geometry of macronutrient balancing and consequences for fat deposition. Obesity 16, 566-571.

35. Veldhorst M, Smeets A, Soenen S, et al. (2008) Protein-induced satiety: effects and mechanisms of different proteins. Physiol Behav 94, 300-307. 